Jurnal Abdidas Volume 2 Nomor 6 Tahun 2021 Halaman 1281 - 1288

JURNAL ABDIDAS

http://abdidas.org/index.php/abdidas

\title{
Pelatihan Inovasi Teknologi Briket dari Tempurung Kenari Program Kemitraan Masyarakat Kelurahan Tarau di Pulau Ternate
}

\author{
Sundari $^{1 \bowtie}{ }^{1}$ Nurhasanah $^{2}$, Numaya Papuangan $^{3}$, Ica Husen $^{4}$, Abdu Mas’ud $^{5}$ \\ Biologi, Universitas Khairun Ternate, Maluku Utara, Indonesia ${ }^{1,2,3,5}$ \\ SMAN 6 Kota Ternate Utara, Maluku Utara, Indonesia ${ }^{4}$ \\ E-mail : sundari@unkhair.ac.id ${ }^{1}$, nurhasanahjusuf@gmail.com², mayapapuangan@gmail.com ${ }^{3}$, \\ icahusen@gmail.com ${ }^{4}$, abdumasud@unkhair.ac.id
}

\begin{abstract}
Abstrak
Program kemitraan masyarakat hasil implementasi penelitian unggulan perguruan tinggi tentang pradesain biobriket dari limbah tempurung kenari berbasis riset kajian nilai kalor dan variasi perekat. Informasi dan produk pengembangan alat yang di desain peneliti perlu disosialisasikan kepada masyarakat di kota Ternate. Hasil analisis sosialisasi transfer teknologi pembuatan briket tempurung kenari dan pengembangan varian produk briket berkorelasi dengan hasil analisis preferensi konsumen terhadap produk briket tempurung kenari. Secara umum masyarakat mitra dapat menerima teknologi pembuatan briket tempurung kenari dan produk briket memiliki potensi untuk dikembangkan berdasarkan analisis preferensi konsumen terhadap produk briket. Briket tempurung kenari dapat dikembangkan oleh masyarakat kelurahan Tarau pulau Ternate. Produk biobriket tempurung kenari dan variasi produk briket aroma terapi rempah dan briket anti nyamuk memiliki potensi ekonomi dikembangkan menjadi usaha bisnis berdasarkan faktor tingkat teknologi yang mudah, ketersediaan bahan baku, tingkat kesukaan masyarakat.
\end{abstract}

Kata kunci: inovasi teknologi, briket, pengabdian masyarakat

\begin{abstract}
The community partnership program is the result of the implementation of leading university research on biobriquette pre-design from walnut shell waste based on research on calorific value and adhesive variations. Information and product development tools designed by researchers need to be disseminated to the public in the city of Ternate. The results of the socialization analysis of the transfer of technology for making kenari shell briquettes and the development of variants of briquette products correlated with the results of the analysis of consumer preferences for kenari shell briquettes. In general, the partner community can accept the technology for making kenari shell briquettes and briquette products have the potential to be developed based on the analysis of consumer preferences for briquette products. Kenari shell briquettes can be developed by the people of Tarau village, Ternate island. Kenari shell biobriquette products and variations of aromatherapy spice briquettes and mosquito repellent briquettes have economic potential to be developed into business ventures based on easy technology, availability of raw materials, and community preference.

Keywords: technological innovation, briquette, community service
\end{abstract}

Copyright (c) 2021 Sundari, Nurhasanah, Numaya Papuangan, Ica Husen, Abdu Mas'ud

$\triangle$ Corresponding author

Address : Universitas Khairun Ternate

Email : sundari@unkhair.ac.id

ISSN 2721- 9224 (Media Cetak)

DOI : https://doi.org/10.31004/abdidas.v2i6.464

ISSN 2721- 9216 (Media Online) 
1282 Pelatihan Inovasi Teknologi Briket dari Tempurung Kenari Program Kemitraan Masyarakat Kelurahan Tarau di Pulau Ternate - Sundari, Nurhasanah, Numaya Papuangan, Ica Husen, Abdu Mas'ud

DOI: https://doi.org/10.31004/abdidas.v2i6.464

\section{PENDAHULUAN}

Analisis Situasi: Pada saat ini terjadi fenomena krisis energi, pemanasan global dan semakin berkurangnya cadangan bahan bakar minyak (BBM) yang berasal dari fosil, memberikan peluang bagi pengembangan dan pemanfaatan sumber energi alternatif (green energy). Salah satu bahan utama sumber energi alternatif yang dimaksud adalah biomassa tanaman yang bersifat dapat diperbaharui (renewable energy). Biomassa merupakan bahan alami yang dianggap sebagai sampah dan sering dimusnahkan dengan cara dibakar. Tempurung kenari merupakan biomassa dari produk pasca panen biji kenari di pulau Makian Maluku Utara. Salah satu pemanfaatan biomassa sebagai bahan bakar alternatif, adalah dengan membuatnya menjadi briket bioarang.

Maluku Utara merupakan salah (Canarium indicum L) di Indonesia. Di pulau Makian tanaman ini tersebar secara melimpah sebagai tanaman hutan. Tanaman kenari merupakan tanaman asli Indonesia dan berpotensi untuk dikembangkan sebagai produk pangan dan obat. Pemanfaatan tanaman kenari oleh masyarakat setempat sampai saat ini hanya pada bagian biji kenari yang digunakan sebagai bahan makanan, dan bahan rempah kue dan masakan. Sementara itu limbah kulit dan tempurung biji Kenari tidak dimanfaatkan. Kulit dan tempurung biji kenari merupakan sumber utama lignoselulosa yang berpotensi untuk pembuatan bahan bakar reneweble energy berbasis pemanfaatan biomassa.

Sementara itu kebutuhan energi bahan bakar minyak mengalami peningkatan seiring dengan laju pertumbuhan populasi manusia dan perekonomian dunia. Di Indonesia, dalam Blue Print Pengelolaan Energi Nasional 2006-2025 yang dirilis oleh Kementerian Energi dan Sumber
Daya Mineral (ESDM), kebijakan energi Indonesia memiliki sasaran antara lain pada tahun 2025 akan tercapai penurunan peranan minyak bumi menjadi $26.2 \%$, gas bumi meningkat menjadi $30.6 \%$, batubara meningkat menjadi $32.7 \%$ (termasuk briket batubara), panas bumi meningkat menjadi $3.8 \%$, dan energi terbarukan meningkat menjadi 15\% (Anonim, 2007). Pemerintah juga menargetkan bahwa pada tahun 2016 pemanfaatan BBN dapat mencapai angka 5\%. Salah satu contoh bahan bakar berbasis nabatia dalah biobriket.

Biobriket merupakan jenis bahan bakar padat yang terbuat dari bahan baku biomassa dengan campuran sedikit perekat. Biomasa dalam kehidupan sehari-hari merupakan bahan hayati yang biasanya dianggap sebagai sampah dan sering dimusnahkan dengan caradibakar (Triono, 2006). Menurut Adan (1998) dalam Sari (2011) keuntungan pemakaian briket arang antara lain, biayanya lebih murah dibandingkan dengan minyak atau arang kayu, briket arang memiliki masa bakar yang jauh lebih lama, penggunaan briket relatif lebih aman, briket mudah disimpan dan dipindah-pindahkan, tidak perlu berkali-kali mengupasi atau menambah dengan bahan bakar yang baru. Dengan berbagai keunggulan tersebut, peran briket arang sebagai bahan bakar alternatif telah diakui di berbagai negara.

Selama ini jenis briket dari arang tempurung kelapa merupakan salah satu sumber energi alternatif favorit dan sangat diminati oleh pangsa pasar dalam negeri maupun ekspor. Briket sebagai komoditas ekspor harus memiliki mutu yang stabil dan dapat memenuhi persyaratan mutu SNI SNI 06-3730-95 (Anonim, 1995). Biobriket yang terbuat dari tempurung kelapa dan bahan sejenis lainnya merupakan salah bentuk energi terbarukan yang layak dikembangkan di Indonesia. Salah satu 
1283 Pelatihan Inovasi Teknologi Briket dari Tempurung Kenari Program Kemitraan Masyarakat Kelurahan Tarau di Pulau Ternate - Sundari, Nurhasanah, Numaya Papuangan, Ica Husen, Abdu Mas'ud

DOI: https://doi.org/10.31004/abdidas.v2i6.464

bahan sejenis tempurung kelapa yang memiliki potensi dikembangkan menjadi biobriket di Maluku Utara adalah limbah tempurung biji kenari.

Hasil penelitain Sundari., dkk (2018) menunjukkan bahwa limbah tempurng kenari memiliki potensi digunakan sebagai bahan baku pembuatan briket. Kualitas briket tempurung kelapa dan tempung kenari memiliki kualitas yang setara. Program kemitraan ini bertujuan untuk menghasilkan produk briket dan membagun suatu model pengembangan teknologi pembuatan obriket berbasis riset unggulan Perguruan Tinggi Universitas Khairun. Selain itu program ini diharapkan dapat menghasilkan luaran kompetensi masyarakat pulau Ternate untuk mengembangkan briket skala rumahan. Selanjutnya program ini dapat dikembangkan kemitraannya dengan masyarakat pengasap ikan fufu agar menggunakan briket untuk proses pengasapan ikan. Keluaran (output) program ini : 1) produk briket tempurung kenari yang berkualitas; 2) kompetensi masyarakat pengrajin briket.

\section{METODE}

Langkah-langkah pelaksanaan program PKM di kelompok masyarakat pengrajin briket di pulau Ternate dapat dideskripsikan sebagai berikut:

\section{Sosialisasi dan Pendekatan program}

Pendekatan yang digunakan dalam program kemitraan ini adalah pendekatan kualitatif (Arikunto, 2002). Pelaksana program dan Mitra merupakan sasaran dan data utama da lam kegiatan ini.

\section{Pelaksana Program}

Pelaksana program PKM ini terdiri dari 2 orang dosen dan 2 orang mahasiswa prodi pendidikan Biologi Universitas Khairun
Ternate. Mitra terdiri dari kelompok ibu PKK di kelurahan Tarau (PKK sasaran) dan masyarakat kota Ternate secara umum.

\section{Waktu dan Tempat}

Program ini akan berlangsung selama 8 bulan yaitu dari bulan Maret sampai dengan Oktober 2019. Lokasi pengabdian di kelurahan Tarau kota Ternate utara dan kelurahan Ngade kota Ternate Selatan .

\section{HASIL DAN PEMBAHASAN}

\section{A. Tahap Persiapan}

Persiapan pelaksanaan pelatihan sosialisasi pembuatan briket tempurung kenari dan pengenalan teknologi pada masyarakat mitra telah dilaksanakan dengan beberapa tahap pembuatan prototipe briket tempurung kenari dengan langkah langkah sebagai berikut:

1) Pembuatan Arang

Proses pengarangan (karbonisasi) tempurung kenari dengan menggunakan teknik kerja sebagai berikut tempurung kenari yang bersih disusun di dalam tempat pengarangan berupa drum besi dan ditutup rapat dan dibakar sampai tempurung berwarna hitam dan menjadi arang.

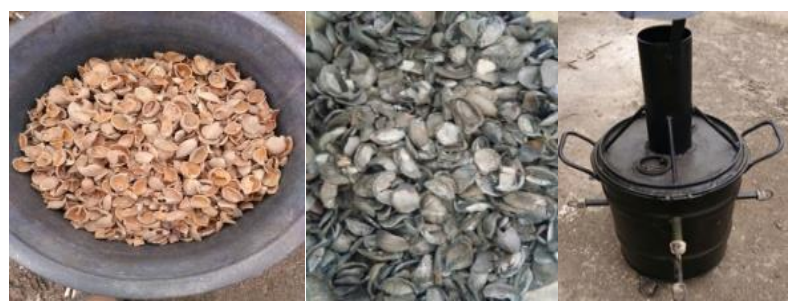

Gambar 1. Proses Pembuatan Arang Tempurung Kenari

\section{2) Persiapan Membuat Briket Arang}

Tempurung kenari yang sudah menjadi arang dihaluskan dengan cara menggunakan alat penumbuk, kemudian di ayak dengan mesh 50 untuk mendapatkan hasil bubuk arang. 

Kelurahan Tarau di Pulau Ternate - Sundari, Nurhasanah, Numaya Papuangan, Ica Husen, Abdu Mas'ud

DOI: https://doi.org/10.31004/abdidas.v2i6.464

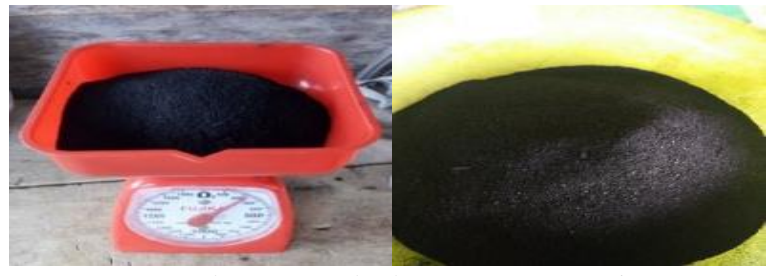

Gambar 2. Bubuk Arang Kenari

\section{3) Pencampuran}

Serbuk arang yang telah diayak halus dengan menggunakan ayakan 50 mesh masingmasing ditimbang sebanyak $1 \mathrm{~kg}$, dicampur dengan perekat 100 gr perekat yang telah dilarutkan dalam $100 \mathrm{ml}$ air 900. Perekat yang digunakan adalah kanji atau tapioka.
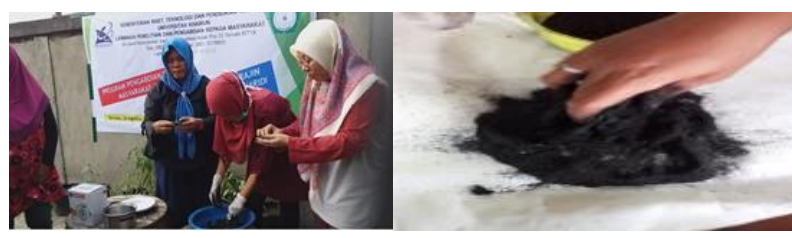

Gambar 3. Proses Pencampuran Bubuk Arang dan Perekat

\section{4) Pencetakan Biobriket}

Pencetakan dilakukan setelah adonan merata, lalu dicetak dengan alat cetak briket manual dengan cara memasukkan campuran adonan briket ke dalam lubang cetak sebanyak 8 lubang, kemudian ditekan atau dipres, dengan sekali pencetakan menghasilkan 8 buah briket arang yang berbentuk silinder.

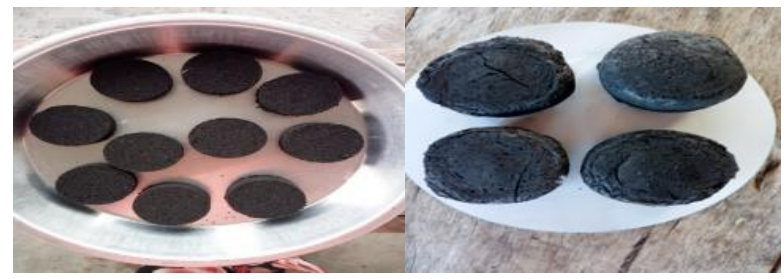

Gambar 4. Pencetakan Briket Tempurung Kenari

\section{5) Pengeringan}

Adonan briket arang dari tempurung kenari yang selesai dicetak akan berbentuk silinder (bulat panjang) yang masih dalam keadaan basah dan rapuh sehingga perlu perlakuan khusus yaitu dikeringkan dengan menggunakan teknik pengeringan oven pengering suhu $125{ }^{0} \mathrm{C}$ selama 48 jam. Atau kering sinar matahari dan udara bebas selama 7 hari.

6) Analisis kualitas briket (ASTM D 5142-02)

Hasil biobriket yang sudah kering selanjutnya diukur kadar air, kadar abu, kadar karbon terikat kadar zat menguap dan waktu mencapai titik didih serta nilai kalor menggunakan bomb kalorimeter. Nilai kalor yang digunakan sebagai standar merujuk pada SNI briket arang batu bara yaitu $>5000 \mathrm{kal} /$ gram. Nilai karakteristik briket bioarang kenari pada penelitian ini meliputi kadar air, kadar abu, kadar karbon terikat dan kadar zat mudah menguap. Nilai tersebut disajikan padaTabel 1

Tabel 1. Analisis Biobriket Kenari

\begin{tabular}{|l|l|l|l|l|l|}
\hline \multicolumn{1}{|c|}{$\begin{array}{c}\text { Variasi } \\
\text { briket }\end{array}$} & $\begin{array}{c}\text { Kadar } \\
\text { air }(\boldsymbol{\%})\end{array}$ & $\begin{array}{c}\text { Kadar abu } \\
(\boldsymbol{\%})\end{array}$ & $\begin{array}{c}\text { Kadar } \\
\text { karbontebrikat } \\
(\boldsymbol{\%})\end{array}$ & $\begin{array}{l}\text { Kadar } \\
\text { zatmenguap } \\
(\boldsymbol{\%})\end{array}$ & $\begin{array}{c}\text { Waktumencapaititikdi } \\
\text { dih 100 ml air }(\mathbf{m e n i t})\end{array}$ \\
\hline Arangkenari + kanji & 4,30 & 12,85 & 55,90 & 27,00 & 26 \\
\hline Arangkenari + sagu & 3,03 & 10,55 & 67,18 & 20,25 & 26 \\
\hline Arangkenari + pulp Kakao & 3,58 & 8,55 & 67,50 & 21,90 & 27 \\
\hline
\end{tabular}


1285 Pelatihan Inovasi Teknologi Briket dari Tempurung Kenari Program Kemitraan Masyarakat Kelurahan Tarau di Pulau Ternate - Sundari, Nurhasanah, Numaya Papuangan, Ica Husen, Abdu Mas'ud

DOI: https://doi.org/10.31004/abdidas.v2i6.464

\section{Analisis Kadar air}

Penetapan kadar air bertujuan untuk mengetahui sifat higroskopis briket bioarang. Kadar air briketbio arang yang dihasilkan pada penelitian ini berkisar antara 3,03 4,30\% (Tabel 1). Kadar air tertinggi diperoleh dari perlakuan dengan penambahan tepung kanji dan terendah dari perlakuan dengan penambahan tepung sagu. Kadar air yang dihasilkan dari penelitian ini memenuhi standar kualitas arang aktif berdasar SNI 06- 3730-95, yaitu maksimal $15 \%$ untuk briket bioarang bentuk serbuk.

\section{Analisis Kadar abu}

Penetapan kadar abu briket bioarang dilakukan untuk mengetahui kandungan oksida logam dalam briket bioarang. Pada penelitian ini kadar abu yang dihasilkan berkisar antara 8,55 12,85\% (Tabel 1). Kadar abu briket bioarang terendah dihasilkan pada perlakuan penambahan pulp kakao dan tertinggi pada perlakuan penambahan tepung kanji. Hasil penelitian kadar abu ini tidak memenuhi standar kualitas arang aktif menurut SNI 06-3730-95, karena kadar abu briket bioarang melebihi $10 \%$ pada semua perlakuan.

\section{Analisis Kadar karbon terikat}

Penentuan kadar karbon terikat briket bioarang bertujuan untuk mengetahui kandungan karbon setelah proses karbonisasi. Kadar karbon terikat yang dihasilkan pada kegiatan ini berkisar antara $55.90 \sim 67,50 \%$ (Tabel 1). Kadar karbon terikat terendah dihasilkan dari perlakuan penambahan tepung kanji dan tertinggi pada perlakuan penambahan pulp kakao. Berdasarkan SNI 06-3730-95, kadar karbon terikat pada penelitian ini semuanya memenuhi syarat karena memiliki karbon terikat lebih besar dari $65 \%$.

\section{Analisis Kadar zat mudah menguap}

Tujuan dari penetapan kadar zat mudah menguap ini adalah untuk mengetahui kandungan senyawa yang mudah menguap yang terkandung dalam briket bioarang pada suhu $950^{\circ} \mathrm{C}$. Pada kegiatan ini, kadar zat mudah menguap yang dihasilkan berkisar antara 20,25 27,00\% (Tabel 1). Kadar zat mudah menguap terendah diperoleh dari briket bioarang dengan perlakuan penambahan tepung sagu dan tertinggi dengan perlakuan penambahan tepung kanji.

Dari hasil penelitian ini semua kadar zat mudah menguap yang dihasilkan tidak memenuhi standar kualitas arang aktif berdasar SNI 06-373095, yaitu mempunyai kadar zat mudah menguap melebihi $25 \%$.

\section{Analisis Waktu mencapai titik didih air}

Tujuan dari penetapan waktu untuk mencapai titik didih air ini adalah untuk mengetahui berapa lama waktu yang dibutuhkan briket bioarang limbah kenari untuk mencapai titik didih air $\left(100^{\circ} \mathrm{C}\right)$ dari $300 \mathrm{ml}$ air. Pada kegiatan ini, waktu untuk mencapai titik didih air berkisar antara $26 \sim 27$ menit (Tabel 1). Waktu untuk mencapai titik didih air tercepat diperoleh dari briket bioarang dengan perlakuan penambahan tepung sagu dan terlama dengan perlakuan penambahan pulp kakao.

\section{B. Tahap Pelatihan dan sosialisasi}

Tahap sosialisasi dengan mitra sudah dilaksanakan melalui kerjasama pengumpulan tempurung kenari dan pembuatan prototipe model pembuatan briket tempurung kenari. Selanjutnya akan disosialisasikan produk briket pada kelompok masyarakat ibu PKK sebagai calon pengrajin briket di kelurahan Tarau yang dilaksanakan pada tanggal 20 agustus 2019 pada kelompok mitra 

Kelurahan Tarau di Pulau Ternate - Sundari, Nurhasanah, Numaya Papuangan, Ica Husen, Abdu Mas'ud

DOI: https://doi.org/10.31004/abdidas.v2i6.464

sasaran pengrajin briket. Hasil kegiatan sosialisasi pembuatan biobriket kepada masyarakat sasaran menunjukkan bahwa transfer teknologi pembuatan biobriket dari tempurung kenari merupakan informasi dan hal baru yang mudah dan murah untuk dilaksanakan; briket tempurung kenari potensi dikembangkan dengan variasi produk. Adapun hasil analisis umpan balik responden mitra sasaran di kelurahan Tarau seperti pada gambar 6 . berikut:

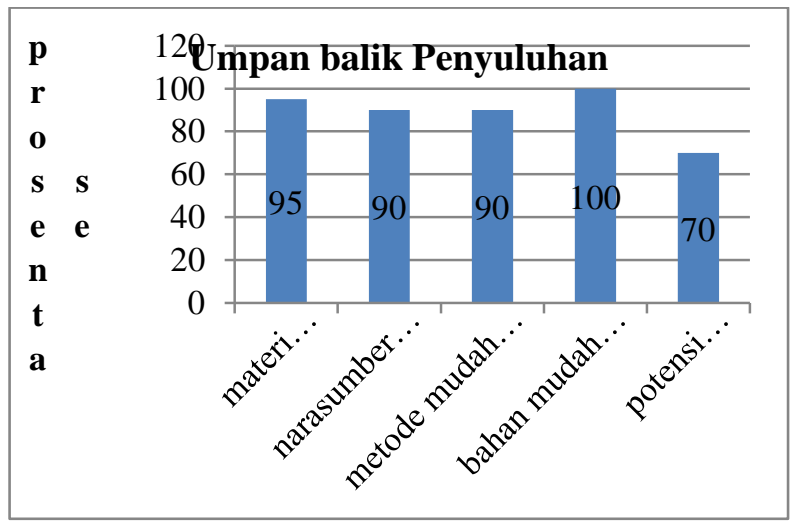

Gambar 6. Umpan Balik Responden

Berdasarkan gambar 6 di atas dapat diketahui bahwa secara umum kegiatan sosialisasi pembuatan briket tempurung kenari dapat diterima oleh mitra sasaran dalam hal ini ibu PKK di kelurahan Tarau kota Ternate Utara.

\section{Tahap Pengembangan dan Evaluasi program}

Tahap selanjutnya adalah pengembangan produk briket tempurung kenari berbasis variasi preferensi konsumen. Pada tahap ini dikembangkan varians produk briket tempurung kenari yaitu variasi briket aroma terapi rempah dan anti nyamuk serta variasi briket original. Uji produk berdasarkan hasil analisis preferensi konsumen masyarakat di kota Ternate seperti gambar 7 berikut:

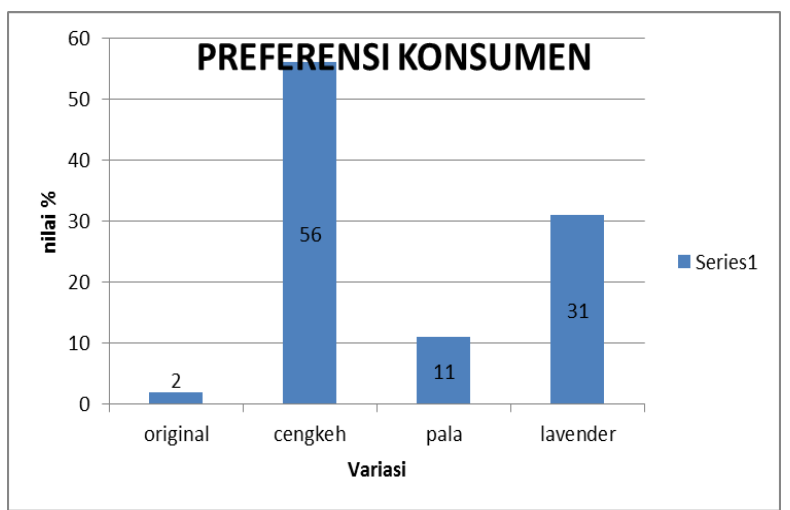

Gambar 7. Preferensi konsumen terhadap variasi produk briket tempurung kenari.

Berdasarkan Gambar 7 diketahui bahwa produk briket tempurung kenari yang divariasi memiliki nilai preferensi konsumen tertinggi adalah briket variasi cengkeh (aroma terapi dan ratus). Selanjutnya briket variasi lavender (anti nyamuk). Briket aroma terapi dan ratus pala kurang disukai karena aroma pala kurang menyengat sedangkan briket original tempurung kenari tidak beraroma

\section{Pembahasan}

Berdasarkan hasil pelaksanaan program kemitraan ini dapat diketahui bahwa teknologi pembuatan briket dari tempurung kenari dapat diterapkan oleh masyarakat di pulau Ternate. Berdasarkan hasil analisis umpan balik responden dikatahui bahwa masyarakat di kelurahan Tarau dan di kota Ternate dapat menerima kehadiran produk briket tempurung kenari sebagai alternatif bahan bakar minyak. Biobriket mempunyai temperatur penyalaan (ignition temperature) yang lebih rendah dan burn out time yang lebih pendek dibandingkan dengan briket batubara. Ketika briket dipanasi temperaturnya naik, setelah mencapai temperatur tertentu, volatile matter keluar dan terbakar disekitar briket. Temperatur ini disebut temperatur nyala. Temperatur nyala turun jika carnpuran biomasa lebih banyak (Naruse, 2001). Menurut Ketaran (1980), arang adalah 
1287 Pelatihan Inovasi Teknologi Briket dari Tempurung Kenari Program Kemitraan Masyarakat Kelurahan Tarau di Pulau Ternate - Sundari, Nurhasanah, Numaya Papuangan, Ica Husen, Abdu Mas'ud

DOI: https://doi.org/10.31004/abdidas.v2i6.464

bahan padat yang berpori-pori dan merupakan hasil pembakaran dari bahan yang mengandung unsur C. Sebagian besar dari pori-porinya masih tertutup dengan hidrokarbon, dan senyawa organik lain yang komponennya terdiri dari "fixed carbon ", abu, air, nitrogen dan sulfur.

Dalam bidang industri dikenal bermacammacam arang yang berhubungan dengan pembuatan dan kegunaannya. arang dihasilkan dari pembakaran bahan baku yang mengandung karbon. Selanjutnya diketahui bahwa produk pengembangan briket tempurung kenari memiliki potensi pasar berdasarakan preferensi konsumen (Sundari, dkk, 2019). Variasi produk briket tempurung kenari dengan aroma terapi rempah cengkeh dan pala serta anti nyamuk ekstrak lavender memiliki preferensi konsumen tertinggi pada produk briket aroma cengkeh dan briket anti nyamuk ekstrak lavender. Salah satu pertimbangan perencanaan bisnis suatu produk adalah faktor tingkat kesukaan konsumen terhadap suatu produk. Tingkat kesukaan konsumen merupakan salah satu peluang usaha dalam perencaaan bisnis.

Peluang usaha bisnis briket tempurung kenari memberikan laba bersih per bulan rata rata 2.100.000 dan ROI Rp. 2. 045.454,55 (Sundari, dkk,2019). Asumsi bisnis briket tempurung kenari dalam penelitian tersebut dilaksanakan secara normatif perusahaan dengan modal usaha mesin dan karyawan serta bahan baku standart minimalis. Hasil penelitian ini masih bersifat parsial bisnis plan skala mikro yang masih melibatkan beberapa faktor yang berpengaruh terhadap rencana bisnis dari sudut pandang proses produksi, ketersediaan bahan baku dan pangsa pasar produk.

Berdasarkan elaborasi hasil pelaksanaan program kemitraan dan penelitian terkait pengembangan produk briket tempurung kenari dapat diketahui bahwa briket tempurung kenari merupakan salah satu alternatif pengembangan bio energi yang memiliki potensi ekonomi cukup menjanjikan bagi masyarakat pulau Ternate.

\section{SIMPULAN}

Berdasarkan hasil dan pembahasan dalam program kemitraan ini maka dapat disimpulkan sebagai berikut:

1. Hasil analisis sosialisasi transfer teknologi pembuatan briket tempurung kenari dan pengembangan varian produk briket berkorelasi dengan hasil analisis preferensi konsumen terhadap produk briket tempurung kenari. Secara umum masyarakat mitra dapat menerima teknologi pembuatan briket tempurung kenari dan produk briket memiliki potensi untuk dikembangkan berdasarkan analisis preferensi konsumen terhadap produk briket.

2. Briket tempurung kenari dapat dikembangkan oleh masyarakat kelurahan Tarau pualau Ternate

3. Produk biobriket tempurung kenari dan variasi produk briket aroma terapi rempah dan briket anti nyamuk memiliki potensi ekonomi dikembangkan menjadi usaha bisnis berdasarkan faktor tingkat teknologi yang mudah, ketersediaan bahan baku, tingkat kesukaan masyarakat.

\section{UCAPAN TERIMA KASIH}

Penulis mengucapkan terimakasih kepada DRPM yang telah memberikan dana Hibah PKM yanun 2019 ini sehingga program Pelatihan pembuatan briket di pulau Ternate dapat terlaksana. 
1288 Pelatihan Inovasi Teknologi Briket dari Tempurung Kenari Program Kemitraan Masyarakat Kelurahan Tarau di Pulau Ternate - Sundari, Nurhasanah, Numaya Papuangan, Ica Husen, Abdu Mas'ud

DOI: https://doi.org/10.31004/abdidas.v2i6.464

\section{DAFTAR PUSTAKA}

Anonim. 1995. "Mutu Dan Cara Uji Arang Aktif Teknis. Standar Nasional Indonesia (SNI) 063730-1995". Dewan Standarisasi. Jakarta.

Anonim, 2007, Briket Batubara Sebagai Alternatif Pengganti Minyak Tanah, Kementrian Negara Riset Dan Teknologi @ 2004.Ristek.Go.Id.

Anonim, 2008, Sekam Padi Sebagai Sumber Energi Alternatif Dalam Rumah Tangga Petani, Badan Penelitian Dan Pengembangan Pertanian, Departemen Pertanian, Bogor.

Hambali E, Dkk, 2007, Teknologi Bioenergi, Agromedia, Jakarta

Mahmud, Z., Ferry, Y. (2005). Prospek Pengolahan Hasil Samping Buah Kelapa. Perspektif, 4(1), 55-63. .

Sari, M. K. (2011). Potensi Dan Peluang Kelayakan Ekspor: Kelayakan Ekspor Arang Tempurungkelapa (Coconut Shell Charcoal) Di Kabupaten Banyumas .Mediagro, 7(2), 6982.

Sarjono. (2013). Studi Eksperimental Perbandingan Nilai Kalor Briket Campuran Bioarang Sekam Padi Dan Tempurung Kelapa. Majalah Ilmiah STTR Cepu, 11(17)11-18.

Triono, A., 2006, Karakteristi Kbriket Arang Dari Campuran Serbuk Gergaji Kayu Afrika (Maesopsiseminiiengl) Dan Sengon (Paraseri Anthesfalcataria L. Nielsen) Dengan Penambahan Tempurung Kelapa (Cocos Nucifera L), Departemen Hasil Hutan Fakultas Kehutanan IPB, Bogor. 